Natalia LemanN

Uniwersytet Łódzki

\title{
Naturalizacja władzy a kolonializm. Uwagi na marginesie Robinsona Cruzoe Daniela Defoe i Piętaszka, czyli Otchłani Pacyfiku Michela Tourniera, z Szekspirowską Burza w tle
}

Robinson Cruzoe Daniela Defoe to kanoniczne dzieło literatury europejskiej, które doczekało się wielu naśladownictw, zwanych robinsonadami (Gazda 939). Analiza historii samego Robinsona i kolejnych robinsonad prowadzi do naświetlenia przede wszystkim walorów dydaktycznych i moralizatorskich opowieści o tryumfie człowieka nad samotnością i naturą, umiejętności przekucia dzikiej, przygodnej natury w cywilizację. Ideologia homo faber, wyrażona najpełniej właśnie w postaci Robinsona, zastępuje wcześniej obecne w literaturze postawy vita completativa. Robinson Cruzoe jest herosem literatury i kultury współczesnej, człowiekiem czynu niepoddającym się marazmowi bezczynności nawet w sytuacji ekstremalnej.

Dowodem jednoznacznie pozytywnej waloryzacji postaci Robinsona w literaturze i kulturze polskiej jest określenie „Robinson warszawski”, określające cywilów ukrywających się w ruinach Warszawy po upadku powstania warszawskiego. Co ciekawe, pierwszy raz użył tego określenia Antoni Słonimski w powieści science-fiction Dwa końce świata (Słonimski). Powieść opowiada o apokalipsie sprowadzonej na świat przez radykalnego wyznawcę ideologii Hitlera, Hansa Retlicha. Ocalały z owej katastrofy Henryk Szwalba, subiekt księgarski, określony jest właśnie mianem Robinsona warszawskiego. W optyce narzuconej przez Słonimskiego i kolejnych użyciach określenia „Robinson warszawski” bohater powieści Defoe staje się wcieleniem cnót człowieka cy- 
wilizowanego, opierającego się siłą woli barbarzyństwu, umiejącego odszukać nadzieję w mrokach i rozpaczy. Z losami Cruzoe utożsamiali się też ocaleli z Holocaustu, w tym Imre Kertesz i Primo Levi (Kraft 39). Dzielny rozbitek, walczący o przetrwanie w ekstremalnie niesprzyjających warunkach, niestrudzony promotor nadziei, jako archetypiczna postać kultury euroatlantyckiej wpisuje się w opisywaną przez Oscara Spenglera „faustyczną duszę” człowieka Zachodu, charakteryzującą się nieustannym dążeniem do polepszenia zastanego stanu posiadania i wiecznym, pełnym trudu poszukiwaniem wiedzy i wyzwań, bezustannym przekraczaniem kolejnych, tkwiących jedynie w umyśle granic i barier.

Różnica między mitycznym Faustem a Cruzoe jest jednak bardzo istotna. O ile Faust, jako centralny topos kultury Renesansu, jest człowiekiem wybitnym: człowiekiem wielkiej wiedzy, magiem, zdolnym naginać prawa przyrody mocą swego umysłu i zaklęć, o tyle Robinson Cruzoe jest zwykłym człowiekiem, „everymanem”, który reprezentuje ideę „nowego początku” (Erickson 51). Różnica pomiędzy figurami Fausta a Robinsona zasadza się między innymi na zmienionych warunkach gospodarki towarowej i pieniężnej. Robinson to modelowy przykład człowieka wczesnego kapitalizmu. Max Weber uznał Robinsona za ideał homo oeconomicus, który wiedziony protestancką etyką pracy realizuje postulaty przekształcania natury i budowania cywilizacji, przydając w ten sposób chwały i dobrobytu królestwu Bożemu na ziemi; człowieka, który traktuje pracę jako wypełnienie powołania danemu człowiekowi przez Najwyższego (Weber). Karol Marks widział w nim dowód zjawiska fetyszyzacji towaru (Marks), twierdząc wprost, iż „ekonomia polityczna lubi robinsonady” (Marks 39). Frederic Bastiat, francuski ekonomista, zwolennik idei wolnego rynku z połowy XIX wieku uznaje Cruzoe za przykład "człowieka, który chroni swoje miejsce pracy” (Bastiat 18-25). Pierre Macherey postrzega działania Robinsona jako realizację absolutnego prawa do „re-formowania” przyrody, ekonomicznego podboju, zmierzającego do stworzenia idealnej ekonomicznej autarkii (Macherey 223, 272). Ian Watt wpisuje go z kolei w proces narodzin nowożytnego indywidualizmu połączonego z rodzącym się kapitalizmem i doskonałe wcielenie idei pełnej autonomii jednostki, również w aspekcie ekonomicznym (Watt).

Niniejszy szkic ma na celu prześledzenie procesów naturalizacji władzy, związanych z rodzącym się kapitalizmem. Zamierzam wykazać, że w zmienionych warunkach ekonomicznych - w czasach procesu industrializacji w przededniu rewolucji przemysłowej, epoce awansu mieszczaństwa i kupiectwa oraz emancypacji tych warstw społecznych kosztem starej arystokracji - dochodzi również do istotnych zmian w podejściu do kategorii władzy i jej źródeł. Proces ten ma duże znaczenie dla procesów kolonizacyjnych, dla rodzącego się właśnie oświeceniowego paradygmatu „dorosłości” cywilizacji Białych, 
przeciwstawionego stanowi „niedojrzałości” stojących cywilizacyjnie niżej kultur pierwotnych (Gandhi 35-38). W celu wyprowadzenia „dzikusów” ze stanu dzieciństwa, w kierunku „światła” cywilizacji”, człowiek Zachodu, biały kolonizator, podejmuje (jednostronne) zobowiązanie społeczne zmierzające do narzucenia kulturom niższym swych wzorów i matryc kulturowych. Połowa XVIII wieku, czas, kiedy Robinson Cruzoe przebywa na wyspie, to w historii świata zachodniego era rodzących się imperiów kolonialnych i niewolnictwa. Ideologia podboju kolonialnego wyrażona była w akronimie ccc: Christianity, Civilization, Commerce. Co bardzo istotne dla moich dalszych rozważań, w źródłosłowie łacińskim słowa cywilizacja znajduje się rdzeń civilis, 'obywatelski, odnoszący się do obywatela'. Aby Robinson Cruzoe stał się źródłem prawa na przejętej w posiadanie wyspie - uczynił ją sobie poddaną, obwieścił się jej królem, a następnie gubernatorem, mógł narzucić swą władzę przyrodzie, zwierzętom, Piętaszkowi a następnie kolejnym ludzkim mieszkańcom wyspy musiało nastąpić przesunięcie w obrębie źródeł legitymizacji władzy z Boskiej na ludzką, firmowaną „umową społeczną”. Jedynym powołaniem Cruzoe, jak zauważa Watt, była „pogoń za zyskiem, a terenem jego działania cały świat” (Watt 75). Jest to efekt nowego podejścia do źródeł władzy; przejście od zwykłego człowieka z kategorii „wasala” do roli i pozycji obywatela, suwerena, którym staje się każdy obywatel żyjący w warunkach państw demokratycznych. To lud, pojmowany jako wspólnota obywateli, staje się suwerenem i to od niego pochodzi legitymizacja władzy. W tej koncepcji źródłem władzy jest więc obywatel, a nie, jak od czasów antycznych, monarcha. Koncepcję powszechnej suwerenności sformułowali myśliciele przełomu XVII i XVIII wieku, między innymi Thomas Hobbes, John Locke, Jean-Jacques Rousseau i inni.

Kiedy Cruzoe przebywa na wyspie, w Europie zachodzą coraz to wyraźniejsze zmiany dotyczące kategorii i źródeł władzy. Pamiętajmy, że w 1649 roku w Anglii zabito Karola I Stuarta po uprzednim zrzuceniu go z tronu, zaś w 1793 roku we Francji zgilotynowano Ludwika Xvi, obywatela „Luisa Capeta”. Były to wydarzenia przełomowe dla formowania się nowożytnej koncepcji narodu jako suzerena, oznaczające porzucenie występujących w kulturze zachodniej od czasów antycznych boskich źródeł legitymizacji władzy. Od wczesnego średniowiecza władca jest traktowany jako namiestnik Boga na ziemi, włada on swym państwem na mocy prawa poruczonego przez Boga. Rytuał sakry królewskiej „zdejmował” z władcy ludzką „powłokę”, w ten sposób władca rodził się po raz kolejny, już jako namiestnik Boży (Lemann 2011). W Anglii i Francji powszechna była wiara w taumaturgię królewską (Bloch), moc leczenia przez pomazańców Bożych powszechnych schorzeń, takich jak skrofuły. W Anglii sformułowano zaś dogmat dwóch ciał króla (Kantorowicz). Persona mixta, a więc niejednorodne 
ciało królewskie, mistycznie podzielone na ciało naturalne i ciało kolegialne, to fundament dogmatu politycznego „król nie umiera nigdy”. Le roi est mort, Vive le roi! Umiera jedynie ciało naturalne króla, podczas gdy jego ciało mistyczne, kolegialne, połączone z całością królestwa i jego wszystkimi mieszkańcami zostaje w mistyczny sposób podjęte przez kolejnego koronowanego monarchę . Państwo nie może być pozbawione swego opiekuna, inaczej bowiem cierpi. Zachodzi tutaj uderzające podobieństwo do wierzeń celtyckich, dotyczących mitu Ziemi Jałowej - król nie może być chory, ułomny czy bezpłodny, ponieważ wtedy jałowieje cała ziemia (Graves; Botheroyd, Botheroyd 104). Literackim wykładem dogmatu dwóch ciał króla jest Ryszard II Williama Szekspira, analizowany zresztą przez samego Kantorowicza w przywołanej pracy. Dramat króla Ryszarda II panującego w Anglii w latach 1377-1399, a więc u początku bratobójczej Wojny Dwóch Róż, stał się pod piórem Szekspira dramatem politycznym o słabości monarchy zwiedzionego pozorami nietykalności i świętości. Obalony przez Bolingbroke’a, czyli późniejszego Henryka Iv, Ryszard II musiał sam dokonać swego złożenia z tronu. Nie było bowiem nikogo, kto dorównując mu stanem, mógłby dokonać jego detronizacji. Ryszard II czyni to sam: „własną mą rękę oddaje koronę" (Szekspir, źródło elektroniczne; akt IV, sc. 1, w. 2226), powtarzając gest pierwotnego rytuału przejścia - sakry królewskiej, w odwrotnej jednak kolejności. Namaszczenie, jego aspekt liminalny, powodował, że następca tronu, stając się Królem, przechodził śmierć symboliczną. Tragedią Ryszarda II było więc to, że z króla musiał stać się na nowo księciem, czyli postacią uśmierconą w rycie sakry królewskiej. Słaby Ryszard II atakowany przez przeciwników dokonuje rozszczepienia swej osoby złożonej z dwóch ciał króla, w swej istocie performatywnej: „Ja też odgrywam różnych ludzi role” (Szekspir, źródło elektroniczne; Akt v, sc. v, wrs. 2802). Odrzuca fikcję nieśmiertelności ciała kolegialnego na rzecz ciała naturalnego (Akt III, sc. 2, w. 1464-1491), następnie sam siebie w dramatycznej scenie składa $z$ tronu (Akt IV, sc. 1, w. 2219-2241). Płacz, mowa, gest ręki zdzierają z króla nalot boskości - człowiek unieważnia Boga, a jest to możliwe tylko i wyłącznie dzięki wolnej woli Ryszarda II, który jako władca słaby i okrutny zdał sobie sprawę z tego, że krzywdzi lud i kala majestat. Umarł Ryszard II, niech żyje Henryk IV, albowiem król nie umiera nigdy! Symbolicznym dowodem na kres wiary w nadprzyrodzone pochodzenie monarchy, namiestnika Boga na ziemi, który musi być konsekrowany przez papieża bądź biskupa, jest koronacja cesarska Napoleona I Bonaparte. Równo

1 Koncepcja ta została wyeksplikowana w Raportach Edmunda Plowdena (1518-1585), prawnika, kanclerza królewskiego, twórcy ideologii królewskiej Tudorów (Kantorowicz 2007: 5-19). 
1004 lata po koronacji Karola Wielkiego (2 XII 1804 r.) Napoleon I bierze koronę z rąk papieża i sam nakłada ją sobie na głowę, a dzieje się to niecałe sto lat opublikowaniu historii Robinsona Cruzoe przez Defoe.

Zanim „odwiedzimy” więc, jak sugerował Marks, Robinsona na jego wyspie i zobaczymy go jako nowoczesnego, demokratycznego everymana, który czyni siebie suwerenem i źródłem prawa, „odwiedźmy” na jego wyspie Szekspirowskiego Prospera. Burza Szekspira (1611) to doskonała ilustracja tzw. „pierwszego etapu kontaktu kolonialnego" (Loomba 18). Prospero to prawowity król Mediolanu i ostatni wielki „mag” epoki Renesansu. Nie jest więc on everymanem, a człowiekiem podwójnie „namaszczonym” do sprawowania władzy, jako władca oraz czarnoksiężnik. Prospero, wyzuty ze swego dziedzictwa, osiedla się na wyspie i sprawuje władzę nad Kalibanem i Arielem, jej rdzennymi mieszkańcami, w oparciu o swą moc czarnoksięską, pozwalającą mu rządzić przyrodą oraz bytami niematerialnymi, duchami. Ania Loomba w analizie metod wytwarzania władzy kolonialnej zwraca uwagę, iż Kaliban sam pokazał Prosperowi cuda swej / już-nie-swej wyspy, zaś czarnoksiężnik nie tylko zabrał mu ziemię, ale równocześnie uczynił go niewolnikiem (Loomba 82). Prospero włada jednak dzięki pomocy magii, Kaliban boi się mocy jego laski czarodzieja.

Prospero uwięził matkę Kalibana, wiedźmę Sykoraks, i w ten sposób zniewolił jej syna oraz poddał swej władzy Ariela, „uwalniając” go „mocą swej sztuki” - rozłupując sosnę, w której Ariel przybywał zamknięty (Akt I, sc. II) uprzednio uwolniony spod władzy Sykoraks. Prospero włada magią, grozi więc zbuntowanemu niewolnikowi Kalibanowi nocnymi kurczami, kolką i ponownym zamknięciem w skale (Akt I, sc. II). W akcie v, w scenie I Prospero, żegnając się z wyspą, odzyskawszy swą dawną pozycję, łamie czarodziejską różdżkę i w głębiny morza wyrzuca księgę zaklęć, wyrzekając się mocy. Staje się zwykłym człowiekiem: „Teraz zniknęły wszystkie czary moje, Teraz o własnych tylko siłach stoję" (Akt v, epilog), który wraca do Mediolanu i prosi o przebaczenie za dokonane w słusznej jednak sprawie nadużycia. W wyobraźni Szekspira i jemu współczesnych, by Prospero mógł zapanować nad wyspą i jej mieszkańcami, niezbywalny był element nadprzyrodzonej legitymizacji władzy. Prospero nie rządzi dzięki strzelbie i zasadom ekonomicznym opartym na sile kapitału i mocy produkcji, a dzięki pochodzącej ze sfery metafizycznej magii.

Tymczasem o 100 lat późniejszy rozbitek, Robinson Cruzoe, podbija wyspę jedynie mocą swej wytężonej pracy i dzięki protestanckiej etyce pracy. „Czyni ziemię sobie poddaną”, wykorzystując zewnątrzsterowne podejście do natury, wpisane w przekaz biblijny. Czyni to jednak jako everyman, siłą swych rąk oraz dzięki wiedzy zdobytej we wcześniejszym życiu w cywilizacji. Na wyspę trafia przez nieposkromioną żądzę majątku. Robinson, osiedlając się w Brazylii, ko- 
rzysta z pracy niewolników przywożonych z Afryki. Co więcej, czysty rachunek ekonomiczny, cnotliwa chęć kumulowania, a nie wydawania majątku sprawiają, iż podejmuje wyprawy do Afryki, skąd przywozi niewolników znacznie tańszych niż ci zakupieni w Brazylii (Defoe 17). Kiedy dostaje się do mauretańskiej niewoli, ucieka z niej przy pomocy Ksury’ego, czarnoskórego niewolnika, którego, trafiwszy na statek, sprzedaje za cenę 60 talarów. Wyrzuty sumienia łagodzi obietnicą, iż Ksury zostanie uwolniony po 10 latach (Defoe 31). Watt w swej analizie powieści Defoe wskazuje, iż Robinson ma mentalność doskonałego księgowego i wszystko, co istotne, przelicza na kapitał; chęć bogacenia się jest jego naczelnym principium, wypierającym podszepty tradycyjnej moralności. Ponieważ w czasach Cruzoe niewolnictwo było usankcjonowane prawnie, Robinson nie ma oporów przed podejmowaniem wypraw po niewolników i wszystkich spotykanych na swej drodze „dzikusów” traktuje jako stojących cywilizacyjnie niżej, zatem objętych surowym „patriarchalnym” patronatem. Jest to dla niego zupełnie naturalne, nie potrzeba księgi zaklęć, wystarczy być białym Europejczykiem, który kieruje się purytańskimi cnotami przedsiębiorczości, realizując w ten sposób postulat „opieki” nad niższymi rasami. Kiedy Robinson trafia na wyspę, podejmuje trud przekształcania wyspy zgodnie ze swą wolą i potrzebami. Z lekką ironią definiuje swą pozycję na wyspie jako udzielnego monarchy, króla, cieszącego się świetnym prosperowaniem swej dziedziny:

Schodziłem ze zbocza do tej rozkosznej doliny, a do smutnych mych myśli przyłączyło się tajemne uczucie radości, że wszystko to jest moje, że oto jestem królem i panem tej całej krainy, prawa moje do niej są niezaprzeczalne; gdybym mógł ją przenieść w zamieszkaną część świata, stałaby się moim dziedzictwem jako posiadłość angielskiego lorda (Defoe 80).

Robinson nie kwestionuje swych praw do wyspy. Są one oczywiste i wynikają z natury: to on jest pierwszym mieszkańcem tej ziemi i ma moc narzucania jej swych praw. Czyż to nie jest doskonała, protokapitalistyczna realizacja amerykańskiego scenariusza kardynalnego, „od pucybuta do milionera”? Robinson przejmuje więc władzę nad wyspą i Piętaszkiem jako coś naturalnego, bo upoważnia go do tego bycie białym, zaradnym Europejczykiem, kapitalistycznym, samowystarczalnym przedsiębiorcą w pogoni za zyskiem i awansem społecznym.

Ciężko pracuje na swój chleb, budując tarasy, siejąc zboże i zbierając plony, więc włada. Wraz z gromadą zwierząt, z braku innych poddanych, zasiada do stołu: „Oto jego królewska mość, pan i władca całej wyspy. Życie wszystkich poddanych było w zupełności zależne od mej absolutnej władzy. Miałem prawo 
wieszać, prowadzić na rusztowanie, nadać i odbierać wolność, a między mymi poddanymi nie było buntowników" (Defoe 112-113). Robinson nie potrzebuje mocy czarodziejskiej różdżki, by zdobyć władzę. Nie potrzebuje księgi zaklęć, by ją utrwalić, wystarczają praca fizyczna oraz wydobyte z wraku narzędzia, w tym proch i strzelba. Badacze kolonializmu podkreślają rolę, jaką broń palna wraz z dominacją tekstualną odegrały w zaprowadzaniu i utrzymywaniu władzy kolonialnej na zdobytych/podbitych terenach. Kiedy pojawia się Piętaszek, uratowany przez Robinsona przed jego krewniakami ludożercami, Robinson zdobywa pierwszego ludzkiego poddanego. Gestem uznania przez Piętaszka władzy Robinsona jest położenie sobie przez chłopca stopy Robinsona - pana - na twarzy (Defoe 150). W tym pierwotnym geście poddaństwa, owocu pierwszego, choć kulturowo już dojrzałego kontaktu kolonialnego, wyraża się Heglowska dialektyka pana i niewolnika. Robinson rządzi Piętaszkiem nie jako srogi władca, powołujący się na nadprzyrodzone umiejętności, a jako dobrotliwy, opiekuńczy ojciec. Piętaszek jest mu bezgranicznie oddany, co wynika z natury - natury trwającego w dzieciństwie kulturowym „dzikusa” i naturalnie wyższej pozycji cywilizacyjnej białego Europejczyka, „uczącego” dzikusa praw cywilizacji. Watt zauważa, że „Kruzoe postępuje jak wierny wyznawca Locke’” (Watt 71), narzucając swą władzę nowym przybyszom. Pierwszym przybyszem uznającym władzę Robinsona jest właśnie Piętaszek, w owym poddańczym geście godzący się na niepisaną „umowę społeczną”, określającą, kto jest panem/królem, a kto poddanym. Robinson podkreśla, że gdyby na to pozwolił, „zacząłby darzyć czcią boską mnie i moją strzelbę" (Defoe 155). Władza Robinsona nad wyspą i Piętaszkiem wynika również z poruczenia Boskiego, choć nie potrzeba dla jej legitymizacji ampułki z olejem przyniesionym z nieba przez gołębicę ani rytuału sakry królewskiej.

Cruzoe zadaje sobie czasem pytanie, dlaczego Bóg popełnił niesprawiedliwość: „oświecając jednych, ukrywa się przed drugimi, a od wszystkich oczekuje jednakowej chwały" (Defoe 154), lecz odpowiada sam sobie:

Bóg jest nieskończenie święty i sprawiedliwy, co wypływa z samej natury Jego istnienia, i inaczej być nie może. A jeżeli ci ludzie zostali go pozbawieni, to chyba za to, że zgrzeszyli przeciwko światłu wiary, które jak powiada Pismo Święte, jest właśnie dla nich prawem, zostali odtrąceni przez takie przepisy, które uznali w swym sumieniu za słuszne, choć ich podstawa nie była nam odkryta (Defoe 154).

Robinson jako stojący cywilizacyjnie wyżej znajduje się bliżej światła i źródła władzy, czyli praw Boskich. Ich wypełnianie zostało mu poruczone jako 
chrześcijaninowi, który studiuje Pismo Święte samodzielnie (jako protestant) i wypełnia jego przykazania. Kiedy Robinson pojawia się na wyspie i przejmuje ją we władanie, nie czyni tego jako namiestnik władcy Anglii. Na podbitej ziemi sam staje się suzerenem, równym prawowitym, dziedzicznym władcom w Europie. Władza pochodzi więc z umowy społecznej oraz z prawa władania daną przez Opatrzność w opiekę dziedziną i nie jest potrzebne żadne dodatkowe upoważnienie. Jedyną konieczną legitymizacją jest umiejętność sprawowania kontroli. Robinson z pewnym upodobaniem określa się więc mianem panującego, ma zamek i letnią rezydencję (Defoe 191), pobrzmiewa w nim duma Anglika, spadkobiercy tych, którzy zrzucili z tronu prawowitego monarchę Karola I Stuarta i, jak pisał Jean-Jacques Rousseau i François-Marie Arouet Voltaire, przewyższyli inne narody w wolności.

Kiedy na wyspie pojawiają się kolejni rozbitkowie, Robinson zmusza ich do uznania swej zwierzchności. Muszą zdać się na jego łaskę (tytułowanego teraz gubernatorem, nadal mającego nad przejętym terem władzę absolutną) oraz podpisać akt poddaństwa. W ten oto sposób zostaje zawarta prawdziwa umowa społeczna pomiędzy poddanymi a Robinsonem jako władcą, źródłem prawa. Robinson powraca na swą wyspę po śmierci ukochanej żony. To ona namawiała go do tego kroku słowami: „Wyobrażam sobie, jak będzie ci przyjemnie, kiedy zobaczysz swoją osadę na wyspie, gdzie panowałeś tak szczęśliwie, że większa część twoich braci, władców świata, powinna ci tego zazdrościć” (Defoe 235). Robinson jest określany mianem brata innych panujących, równego koronowanym i namaszczonym władcom świata! Kiedy Robinson wraca na łono cywilizacji europejskiej, a wcześniej do swej plantacji w Brazylii, jego władza monarsza ustaje, choć wciąż wyraża się w autarkicznej mocy sprawowania rządów we własnej plantacji. To na wyspie jednak Robinson jest równy koronowanym i namaszczonym głowom. I rzeczywiście, kiedy Cruzoe powraca na wyspę, osadnicy „zaczęli mnie wszyscy witać po kolei, nie jak majtkowie lub pospolici ludzie, lecz jak gdyby byli ambasadorami wielkich panów, a ja królem lub potężnym zdobywcą" (Defoe 255). W sposób naturalny rodzi się wiec hierarchia władzy: Robinson jest królem, zdobywcą, zaś część osadników sprawuje władzę na zasadach demokratycznych jako przedstawiciele wyłonieni przez naród zamieszkujący wyspę. Dzieje wyspy Robinsona można więc odczytać jako metaforę zdobywania władzy i jej przekształcania się w toku funkcjonowania państwa. Mimo pojawienia się na wyspie buntowników władza Robinsona nie jest kwestionowana. Robinson mówi:

Pochlebiało mi, że byłem patronem moich wyspiarzy, żem się o nich troszczył w sposób wyniosły i majestatyczny, jakby jaki dawny patriar- 
chalny monarcha, zaopatrując ich we wszystko, jakbym był ojcem całej osady i plantacji. Ani myślałem jednak zakładać osadę na rzecz jakiego rządu lub narodu, uznawać władzę jakiegoś panującego czy nazywać moich wyspiarzy poddanymi jakiego bądź kraju, nie postało mi nawet w głowie nadanie imienia mojej wyspie; zostawiłem ją tak, jak zastałem, nie należącą do nikogo, a jej mieszkańców nie podlegających nikomu i nie znających innej władzy prócz mojej. Przecież jakkolwiek wielki miałem wpływ na nich jako ich dobroczyńca i opiekun, władza moje nie miała innej rękojmi jak tylko dobrowolną ich zgodę (Defoe 355).

Robinson nie zamierza zrzekać się władzy na korzyść innego europejskiego suzerena ustanowionego mocą sakry królewskiej, bo on, Robinson Cruzoe, jako władca wyspy jest równy koronowanym głowom. Źródłem władzy Robinsona nad wyspiarzami nie jest więc taumaturgia, sakra królewska, lecz umowa społeczna, pierwotnie zawarta z samą naturą i Piętaszkiem, następnie zaś z pozostałymi osadnikami. Władza Cruzoe nad Piętaszkiem, dzikusem, wynika z praw „naturalnych”, wspomaganych strzelbą i wiedzą, podczas gdy władza nad osadnikami pochodzenia europejskiego wynika z umowy społecznej. Ta różnica jest bardzo istotna, jeśli chcemy zrozumieć historię imperializmu europejskiego. Stojące niżej kultury, wciąż trwające w okresie „dziecięctwa”, „nie dorosły” do bardziej demokratycznych sposobów sprawowania i legitymizacji władzy...

Michel Tournier, francuski pisarz opublikował Piętaszka, czyli otchłanie Pacyfiku w roku 1967 (Tournier), a zatem już w czasach rozpoczynających się procesów postkolonialnych. Powieść tę można więc zaliczyć do nurtu powieści postkolonialnych, pisanych w duchu Saidowskiej lektury kontrapunktowej (Said 53), opisującej przez figury Piętaszka i Robinsona dynamikę stosunków kolonialnych: od zniewolnienia do „uwolnienia” i z powrotem, bo zdaniem Tourniera kolonializm nie kończy się nigdy, gdyż człowiek nie potrafi wyrzec się raz zdobytej władzy.

Francuski pisarz odmiennie widzi historię zdobywania przez Robinsona władzy nad wyspą, zwaną tutaj Speranzą. Robinson początkowo nie podejmuje wysiłków, by „ucywilizować” wyspę. Nie sieje, je jedynie to, co podsuwa mu sama natura. Owo wkomponowanie się rozbitka w cykl naturalnego życia nie oznacza jednak porzucenia przez niego myśli o uczynieniu Speranzy poddaną swej woli. Kiedy Robinson dostrzega odcisk swej stopy (musi być on jego, skoro jest jedynym mieszkańcem), rodzi się w nim duma, iż „Speranza - jak jedna $\mathrm{z}$ tych krów na argentyńskiej prerii, na wpół dzikich, ale naznaczonych rozpalonym żelazem - nosiła odtąd pieczęć swego pana i władcy” (Tournier 45). 
To właśnie wtedy pojawia się w myśli rozbitka obsesja władzy, wprzęgnięcia natury w rytm swych pragnień. Zadaje więc wyspie „potężną dawkę racjonalności” (Tournier 52) i nazajutrz kładzie podwaliny pod Muzeum Miar i Wag (Tournier 52), następnie zaś wznosi forty i pałace, funduje Pałac Sprawiedliwości oraz Świątynię, a także pisze konstytucję wyspy. Jest sam, więc staje się równocześnie suwerenem piszącym prawo, wymiarem sprawiedliwości je wymierzającym oraz karanym za nieposłuszeństwo poddanym. Jest gubernatorem, który niestety nie może skazywać na karę śmierci za nieposłuszeństwo, gdyż brak mu środków do wykonania kary (Tournier 56). Racjonalny projekt trójpodziału władzy współistnieje w umyśle Robinsona $\mathrm{z}$ archaicznymi, kontynuowanymi przez opisywaną powyżej średniowieczną angielską koncepcję dwóch ciał króla, boskimi podstawami władzy królewskiej. Dwa ciała: królewskie i ludzkie, władcy i poddanego, natura królewska i ludzka, współistnieją w ciele i umyśle Robinsona, człowieka nieumiejącego wyjść mentalnie poza charakterystyczny dla ludzi jego czasu schemat pana i niewolnika. Jest bowiem tak mocno związany z wyspą, że traci świadomość granic; pyta, gdzie kończy się Robinson, zaczyna zaś Speranza (Tournier 67, 73). Rychło wchodzi w kontakty seksualne z wyspą, z których rodzą się „córki mandragory”. Nietrudno dostrzec tutaj ślady badanej przeze mnie celtyckiej koncepcji władzy, wynikającej z symbolicznego, magicznego związku pomiędzy królem a jego królestwem (Lemann 2009). Król, z braku ludzkiej królowej, symbolizującej ziemię i jej płodność, wchodzi w stosunki erotyczne z samą ziemią, nakłaniając ją tym samym do posłuszeństwa jego woli. Robinson kocha Speranzę tak, jak król kocha swą ziemię i królową. Wkrótce okaże się, że jest o ziemię zazdrosny jak mąż o żonę. W miłosnym uniesieniu cytuje wyspie frazy Pieśni nad Pieśniami; od miłosnego szału zielenieją łąki, jego broda wrasta głęboko w korzenie wyspy (Tournier 101). Oto metaforyczne opisanie mechanizmu „kolonialnego pożądania” (Young). Cruzoe Tourniera wie, że jedynym ratunkiem przed osunięciem się jego samego i wyspy w chaos jest poddanie się jej absolutnej władzy. Dlatego też czasami zastanawia się nad jej wysadzeniem, bo możliwość uczynienia tego jest najpełniejszym potwierdzeniem jego władzy (Tournier 76).

Co ciekawe, kiedy tylko Robinson ustanowił i spisał prawa wyspy, pojawiają się Araukanie, a zaś z nimi Piętaszek. Najpierw więc pojawia się spisane, ustanowione prawo, następnie zaś pojawia się poddany. Piętaszek w powieści Tourniera jest podwójną aberracją, jest metysem, owocem związku wielorasowego, ma w sobie krew Araukanina oraz Murzyna. Robinson nadaje mu więc imię niebędące ani nazwą własną, ani rzeczownikiem pospolitym, a czymś pomiędzy, tak jak sam Piętaszek znajduje się pomiędzy stanem ludzkim a zwierzęcym (Tournier 108): 
Piętaszek jest chodzącą potulnością. W gruncie rzeczy Piętaszek umarł, w chwili gdy czarownica wycelowała w niego swój sękaty palec. Uciekło ciało bez duszy, ślepe ciało, tak jak kaczki z obciętą głową zrywają się do lotu, bijąc skrzydłami. Ale to ciało pozbawione duszy uciekło nieprzypadkowo. Pobiegło dlatego, żeby połączyć się ze swoją duszą, a tak dusza znajdowała się w ręku białego człowieka. Od tej chwili Piętaszek należy do białego człowieka duszą i ciałem. Cokolwiek mu rozkaże jego pan, jest dobre, czegokolwiek mu zabroni, jest złe (Tournier 110).

Oto doskonała metafora stosunków kolonialnych.

Robinson czuje jednak, że Piętaszek zagraża jego władzy nad wyspą, dlatego też karze go wyjątkowo surowo nawet za najdrobniejsze przewinienia. Czyniąc to jednak, dostrzega w sobie potwora (Tournier 114). Robinson staje się kolejnym wcieleniem Kurtza z Jądra ciemności, któremu absolutna władza nad innym człowiekiem skaziła duszę. Piętaszek jest Robinsonowi konieczny jako poddany, równocześnie jednak jako taki stanowi zagrożenie dla jego absolutnego, niemal wsobnego związku z wyspą. Piętaszek jest ciałem obcym (Tournier 123), zagrażającym władzy absolutnej Robinsona. Oto paradoks władzy: poddany jest konieczny, by władza była realna, jest jednak równocześnie niebezpieczny jako potencjalny rywal. Kiedy więc Robinson, niczym w średniowiecznej opowieści o Tristanie i Izoldzie, przyłapuje chłopca na związku miłosnym z wyspą, musi zareagować, bo oto kruszy się jego władza. Wyspa została zbrukana i zdradziła swego władcę niczym królowa starego króla z młodym uzurpatorem. Ukarawszy srogo Piętaszka, doprowadził jednak do rebelii. Chłopiec „przez przypadek" podpala posiadłości. Cała władza Robinsona, ufundowana na przemocy i racjonalności, na fortach i Muzeum Miar i Wag, płonie. Cruzoe przebacza Piętaszkowi ów akt destrukcji, a stosunki między nimi stają się braterskie. Po raz pierwszy Robinson dostrzega człowieczeństwo i piękno Piętaszka i widzi w nim człowieka i brata. Nie oznacza to pełnej równości, gdyż nadal to Robinson jest władcą. Władza Robinsona jest jednak od teraz potwierdzana również w akcie performatywnego, karnawałowego rytuału świata na opak, owego misterium władzy praktykowanego przez wszelkie kultury i ustroje świata. Piętaszek lubi czasem odgrywać pana, zaś Robinson wciela się wtedy w niewolnika. Pan i niewolnik są więc swymi lustrzanymi odbiciami, swoistym ekonomicznym dopełnieniem, gwarantem trwania świata i porządku zachodnich, binarnych, patriarchalnych, fallocentrycznych opozycji. Inaczej niż w oryginale Defoe Robinson jest tak uzależniony od patriarchalnej absolutnej władzy, że nie opuszcza wyspy, choć ma taką możliwość. Wyspę opuszcza jednak Piętaszek i udaje się do Europy. Zamieszkać na wyspie postanawia jednak jeden z białych 
marynarzy. Robinson, niczym Kaliban w Burzy Szekspira, bierze chłopca za rękę, by pokazać mu wyspę. Porządek władzy został jednak ustanowiony uprzednio, zatem chłopiec zyskuje imię Czwartka. Suweren może być tylko jeden, biały majtek zostaje wprzęgnięty w relacje władzy na wyspie...

Tournier, pisząc swą powieść w przededniu poststrukturalistycznej dekonstrukcji dyskursu władzy i binarnych, fundujących wszelką hierarchię opozycji, obdarza Robinsona pewną dozą nadświadomości wobec pierwowzoru z powieści Defoe. Tournierowski Cruzoe wielokrotnie odwołuje się do porządku solarnego władzy. Na Speranzy Robinson jest królem, a równocześnie słonecznym bóstwem i zastanawia się, czy „gdyby powrócił do Anglii, może zdołałby nie tylko zachować w sobie słoneczną szczęśliwość, której dostąpił, lecz ustanowić jej panowanie w państwie ludzi?” (Tournier 175). Tournierowski Robinson jest opętany ideą rządów absolutnych, jest Narcyzem zakochanym w swym odbiciu: w swych poddanych (Tournier 68). Piętaszek, czyli otchłanie Pacyfiku to powieść o uwiedzeniu przez władzę absolutną. O ile Defoe czyni Robinsona perfekcyjnym homo oeconomicus, człowiekiem czynu, który przekształca wyspę zgodnie z nakazami protestanckiej etyki pracy i Biblii i kieruje się ideami umowy społecznej, postrzegając swą zwierzchność jako pewnego rodzaju posłannictwo i nagrodę za trud, o tyle Tournier widzi Robinsona jako władcę, który nie musi w żaden sposób legitymizować swego panowania, gdyż ta nie potrzebuje żadnych dodatkowych uzasadnień, bo taka jest natura władzy; jeśli istnieje król, muszą istnieć poddani. Król zaś jest istotą boską, ponieważ jest królem. W powieści Tourniera błędne koło natury panowania nie potrzebuje wyjaśnień, choć czytelne jest odwołanie do archaicznych mechanizmów legitymizacji władzy polegających na przekazaniu władcy sprawczości boskiej.

Defoe napisał apologię czynu, który uzasadnia i niejako naturalizuje mechanizmy zdobywania zwierzchności nad pozyskanymi przez białych Europejczyków terenami, zaś Tournier widzi w postaci Robinsona nie apologię vita activa, nie wcielenie kolonialnej ideologii i misji wyrażonej w postaci przywoływanego akronimu ccc, uzasadniającego i usprawiedliwiającego rządy sprawowane w imię ojcowskiej „opieki” nad znajdującymi się w stanie dzikości, ale jako apologię władzy jako takiej: samostanowiącej się, samouzasadniającej się zwierzchności białego człowieka nad innymi rasami... Postać Robinsona i jego życie na wyspie są doskonałym symbolem ideologii kolonialnego podboju i opieki z XVIII wieku, kiedy to rodziły się nowożytne, europejskie imperia kolonialne. Powieść Tourniera jest zaś kontrapunktową, metaforyczną opowieścią o kolonializmie dojrzałym, ustabilizowanym, świadomym i samozwrotnym, rodem z późnego XIX i początków XX wieku. 
W niniejszym szkicu, odwołując się do figur i postaci Prospera i Robinsona (w wersji Daniela Defoe i Michela Tourniera), pokazałam przemiany zachodzące w obrębie kulturowego imaginarium dotyczącego zdobywania i sankcjonowania władzy, w tym kolonialnej. W pierwszym etapie kolonializmu symboliczną figurą władcy jest mag Prospero, odwołujący się do nadnaturalnych źródeł swej potęgi; w czasie tworzenia się imperiów kolonialnych jest to Robinson Cruzoe z powieści Daniela Defoe: homo oeconomicus, zdobywający władzę ciężką pracą, przekształcający stan natury dla wspólnego dobra, sprawujący opiekę nad swymi poddanymi, wyłoniony dzięki zasadzie umowy społecznej; w epoce schyłkowego, drapieżnego etapu eksploatacji kolonialnej jest to Robinson w wersji Michela Tourniera: władca niemal boski, przeglądający się w oczach swych poddanych Narcyz zakochany w idei władzy, która nie potrzebuje dodatkowej sankcji poza samą żądzą władania.

\section{| Bibliografia}

Bastiat, Frederic. Sofizmaty ekonomiczne. Red. M. Wojteńsko. 2008.

Web. 09.12.2019. <http://www.bastiat.pl/>

Bloch, Marc. Królowie cudotwórcy. Studium na temat nadprzyrodzonego charakteru władzy królewskiej zwłaszcza we Francji i Anglii. Wstęp J. Le Goff. Przeł. Jan Maria Kłoczowski. Warszawa: Volumen. Bellona, 1998.

Botheroyd Sylvia, Botheroyd Paul. Słownik mitologii celtyckiej. Przeł. Zygmunt Kubiak. Katowice: Książnica, 1998.

Ceran, Waldemar. „Cesarz w politycznej teologii Euzebiusza z Cezarei i nauczaniu Jana Chryzostoma”. Acta Universitatis Lodziensis. Folia Historica 44 (1992). S. 13-26.

Defoe, Daniel. Przypadki Robinsona Cruzoe. Przeł. t. 1: Józef Birkenmajer; t. 2: przekład anonimowy. Oprac. G. Sinko. Warszawa: PIw, 1983.

Erickson, Robert. "Starting Over Robisnon Cruzoe". Studies in Literary Imagination 15 (1982). S. 51-73.

Faber, Gustav. Merowingowie i Karolingowie. Przeł. Zbigniew Jaworski. Warszawa: PWN, 1994.

Gandhi, Leela. Teoria postkolonialna. Wprowadzenie krytyczne. Przeł. Jacek Serwański. Poznań: Wydawnictwo Poznańskie, 2008.

Gazda Grzegorz, red. Słownik rodzajów i gatunków literackich. Warszawa: PWN, 2012.

Graves, Robert. Biała boginii. Przeł. Ireneusz Kania. Warszawa: Wydawnictwo Alfa, 2000. 
Kantorowicz, Ernst. Dwa ciała króla. Studium ze średniowiecznej teologii politycznej. Przeł. Maciej Michalski, Adam Krawiec. Warszawa: PwN, 2007.

Kraft, Elizabeth. "The Revaluation of Literary Character: The Case of Cruzoe". South Atlantic Review 4 (2007). S. 37-58.

Lemann, Natalia. „Motyw miłości po śmierci - czyli co literatura zawdzięcza Celtom. Garść subiektywnych uwag na marginesie literatury światowej”. Miłość romantyczna jako figura wyobraźni. Seria Antropologia miłości. Red. B. Płonka-Syroka, E. Rudolf. Wrocław: Arboretum, 2009. S. 63-79.

Lemann, Natalia. „Tęsknota za Boskością. Królowie cudotwórcy i pomazańcy Boży w literaturze i kulturze. Szkic antropologiczno-historyczno-literacki”. Władca, władza. Literackie doświadczenia Europejczyków. Wiek xx i xxI. Red. M. Poradecki. Łódź: Wydawnictwo Uniwersytetu Łódzkiego, 2011. S. 19-31. Loomba, Ania. Kolonializm/Postkolonializm. Przeł. Natalia Bloch. Poznań: Wydawnictwo Poznańskie, 2011.

Macherey, Pierre. A Theory of Literary Production. London\&New York: Routledge, 2006.

Marks, Karol. Kapitał. Krytyka ekonomii politycznej. Przeł. Jerzy Heryng, Mieczysław Kwiatkowski, Henryk Gustaw Lauer, Ludwik Selen. Warszawa: PwN, 1951.

Montaigne de, Michel. Próby. Przeł. Tadeusz Boy-Żeleński. Warszawa: Hachette, 2009.

Ossowska, Maria. „Klasyczny model moralności mieszczańskiej: Beniamin Franklin”. Antropologia kultury. Antologia tekstów. Red. A. Mencwel et al. Warszawa: Wydawnictwo Uniwersytetu Warszawskiego, 2005. S. 506-514.

Rousseau, Jean-Jacques. Rozprawa o pochodzeniu i podstawach nierówności między ludźmi. Przeł. Bronisław Minc, Edward Lipiński. Warszawa: PwN, 1954.

Said, Edward. Kultura i imperializm. Przeł. Monika Wyrwas-Wiśniewska. Kraków: Wydawnictwo Uniwersytetu Jagiellońskiego, 2009.

Słonimski, Antoni. Dwa końce świata. Książka i Wiedza: Warszawa, 1937.

Spivak, Gayatri Chakravorty. „Krytyka postkolonialnego rozumu. W stronę historii zanikającej współczesności”. Teorie literatury xx wieku. Antologia. Red. A. Burzyńska, M.P. Markowski. Przeł. Janusz Margański. Kraków: Znak, 2006. S. 650-673.

Szekspir, William. Burza. Przeł. Leon Ulrich. Web. 19.12.2019. <https://wolnelektury.pl/katalog/lektura/burza.html>

Szekspir, William. Król Ryszard II. Przeł. Leon Ulrich. Web. 19.12. 2019. <https:// wolnelektury.pl/katalog/lektura/krol-ryszard-ii.html>

Tournier, Michel. Piętaszek, czyli otchłanie Pacyfiku. Przeł. Maria i Cezary Gawrysiowie. Warszawa: PIW, 1977.

Watt, Ian. Narodziny powieści. Studia o Defoe’em, Richardsonie i Fieldingu. Przeł. Agnieszka Kreczmar. Warszawa: PIW, 1973. 
Weber, Max. Etyka protestancka a duch kapitalizmu. Przeł. Jan Miziński. Lublin: Test, 1994.

Young, Michael. Colonial Desire: Hybridity in Theory, Culture and Race. London: Routledge, 1995.

\section{| Abstrakt}

\section{Natalia Lemann}

Naturalizacja władzy a kolonializm. Uwagi na marginesie Robinsona Cruzoe Daniela Defoe i Piętaszka, czyli Otchłani Pacyfiku Michela Tourniera, z Szekspirowską Burza w tle

Artykuł poświęcony jest analizie zmieniających się w kulturze europejskiej mechanizmów legitymizacji władzy. Robinson Cruzoe Daniela Defoe lokowany jest tradycyjnie w obrębie wczesnokapitalistycznego wzrostu indywidualizmu, przejawiającego się na polu ekonomicznego działania jednostki. Argumentuję, że aby Robinson mógł stać się na swej wyspie homo oeconomicus, który wyłącznie swą pracą przekształca dziką naturę w cywilizację, a następnie zostać władcą/ królem/gubernatorem wyspy, musiały zajść zmiany w obrębie źródeł legitymizacji władzy. Robinson Cruzoe, everyman, może stać się władcą swej wyspy dzięki odejściu od boskiej legitymizacji władzy, która dominowała w kulturze europejskiej, począwszy od antyku, aż do czasów Oświecenia. Przywołuję więc postać Szekspirowskiego Prospera, maga i króla Neapolu, który włada swą wyspą przy pomocy magii jako ostatni literacki potomek „królów cudotwórców” (M. Bloch, E. Kantorowicz). Władza Robinsona opiera się za zasadach umowy społecznej i nie pochodzi z boskiego nadania. Analizuję opisywany przez Defoe mechanizm zdobywania i utrzymywania władzy przez Cruzoe, odwołując się do procesualności powstawania imperiów kolonialnych. Piętaszek, czyli otchłanie Pacyfiku Michela Tourniera z 1967 roku to powieść powstała w optyce Saidowskiej „lektury kontrapunktowej”, dlatego też Tournier dekonstruuje mechanizm naturalizacji, demokratyzacji władzy Robinsona, odwołując się do wcześniejszych mechanizmów metafizycznej legitymizacji. Dostrzegam więc procesualność mechanizmu zdobywania i utrzymywania władzy, co wydaje mi się istotne z punktu widzenia zrozumienia istoty i dynamiki imperializmu kolonialnego.

Słowa kluczowe: władza, postkolonializm, wczesny kapitalizm, taumaturgia, umowa społeczna 


\section{| Abstract}

Natalia Lemann

Naturalisation of Power. Some Notes on the Margins of Daniel Defoe's Robinson Crusoe and Michel Tournier's Friday, or, The Other Island with the Shakespearean Tempest in the Background

This article is devoted to the analysis of the changing mechanisms of power legitimization in the European culture. Daniel Defoe's Robinson Crusoe is traditionally located within the early capitalist growth of individualism, manifested in the field of the economic activity of the individual. I argue that for Robinson to become a homo oeconomicus on his island, a person who transformed wild nature into civilization with his work, and then become the ruler/king/governor of the island, changes within the sources of legitimacy of power had to take place. Robinson Crusoe, an everyman, could become the ruler of his island only by means of resignation from the divine source of power legitimization which dominated European culture from antiquity to the times of Enlightenment. I recall the figure of Shakespearean Prosper, a magician and the king of Naples, who rules his island with the help of magic, as the last literary descendant of "the king's thaumaturge" (M. Bloch, E. Kantorowicz). Robinson's power is based on the principles of a social contract and his authority does not come from divine conferral. I analyse the mechanism of acquiring and maintaining power by Crusoe, described by Defoe, referring to the processuality of forming colonial empires. Friday, or, the Other Island by Michel Tournier, published in 1967, is a novel based on Said's optics of "counterpoint reading", which is why Tournier deconstructs the mechanism of naturalisation, democratisation of Robinson's power, referring to earlier mechanisms of metaphysical legitimacy. This is why I notice the processuality of the mechanism of acquiring and maintaining power, which seems important to me from the point of view of understanding the essence and dynamics of colonial imperialism.

Keywords: power, postcolonialism, early capitalism, thaumaturgy, social contract

\section{| Nota o autorze}

Natalia Lemann - dr, adiunkt w Katedrze Teorii Literatury, w Instytucie Kultury Współczesnej, Uniwersytet Łódzki. Posiada magisterium z historii i filologii polskiej. Zainteresowania naukowe badaczki koncentrują się głównie wokół związków literatury z naukami historycznymi, motywacji mitycznych litera- 
tury współczesnej, literatury fantasy i science-fiction, historii alternatywnych, steampunku oraz antropologii literatury i komparatystyki literackiej, a także metodologii postkolonialnej. Autorka m.in. monografii pt. Historie alternatywne i steampunku w literaturze. Archipelagi badawczo-interpretacyjne (2019), Epicka historiografia we współczesnej prozie polskiej (2008) oraz ponad 70 artykułów zamieszczonych w wysoko punktowanych periodykach i tomach zbiorowych. E-mail: natalia.lemann@uni.lodz.pl ORCID: 0000-0003-2972-9404 
